\title{
On The Frontiers of Central Europe: Ukrainian Galicia at the Turn of the Millennium
}

ANDRIY ZAYARNYUK

\section{THE EVENT}

One August, an Emperor's birthday was celebrated with an scholarly seminar and an artistic performance. An exhibition of the Emperor's portraits was also organized. Participants in the seminar, representing the "scholarly, political, intellectual and artistic elite of the city," signed a petition urging the state administration of the region, the city's mayor, and the city's community "to support our initiative and to honor the Emperor in an adequate way," - by erecting a monument to the Emperor.

The date was the $18^{\text {th }}$ of August and the Emperor in question was Franz Joseph I, which would not be so surprising if not for the fact that the city in which this event took place was L'viv and the year 2000. L'viv celebrated the $170^{\text {th }}$ anniversary of the Emperor's birthday exactly a week before the celebration of the ninth anniversary of Ukraine's independence. The petition signed by the participants in the seminar stated that: "this monument should also become a very special symbol-testimony of our choice of Europe and our will to co-exist in the circle of free and independent nations of Central Europe."

To start with, I do not think that these events were just a chronological coincidence. I believe that the juxtaposition of these two events, the tribute to Franz Joseph I and Independence Day, was made on purpose. The events held during the birthday celebration differed significantly from the official pompous celebrations of Independence Day the following week. It is worth noting, for example, that the artistic performance "Waiting for a ..." was organized by Volodymyr Kaufman, the director of the first and thus far only postmodern performance staged at the L'viv opera ("Chrysler Imperial") during the urban carnival called Vyvykh in the early 1990s. Self-irony, burlesque rituals like searching for the ghost of the Emperor, and implicit sacrilegious comparisons between him and the Messiah were part of the birthday celebration. On the other hand, it was not just a bohemian event: two basic presentations for the seminar - "The 
birthday of a new epoch" and "Franz Joseph at his office" - were prepared by leading researchers at the Center for Political Research of a quite serious political party, "Reforms and Order."

Media coverage of the events was also quite serious. The headline in the official newspaper of the regional administration declared: "Monument will stand by next year to celebrate the $85^{\text {th }}$ anniversary of Franz Joseph's death." ${ }^{2}$ The new L'viv radio station "New Wave" on that day played only "Central European music" and we must remember that the issue of broadcasting music became highly political this summer in L'viv because of the beating and death of the Ukrainian composer and singer Ihor Bilozir, which was represented as the cultural side of the national conflict. ${ }^{3}$ The slogan of the celebration - "in the past we are searching for traces of the future" - stressed the agency of the celebration and its political aspects. ${ }^{4}$

The most serious part of the event was, of course, the "scientific seminar." According to Taras Batenko (one of those presenting at the seminar): "We have Franz Joseph to thank for many, many things. First of all, for the tradition of parliamentary democracy, for the tradition of an organized social-political life, for having a political elite, for the tradition of a real multi-party system, real competition and discussion of political ideologema." Telling the story of how the Ukrainian national movement matured to a state life of its own in AustriaHungary, Taras Batenko stated: "I am not sorry that as a historian I started with the Austrian period because I see the unity in the political progress of the Ukrainian movement since the beginning of the nineteenth century up to our time." According to Taras Batenko, Franz Joseph I is a symbol of "hope and faith" and "with him the Ukrainian symbolic queue [meaning the gallery of national heroes] reaches its former greatness." These were the last words of his presentation..$^{5}$ In general, it would appear that the artistic part of the celebrations and its bohemian overtones camouflaged the more serious issue at stake.

\section{THE CONTEXT}

How were these events interpreted? In an article analyzing the event that appeared in the weekly Polityka $i$ kul'tura, Volodymyr Paliiv wrote that this "longing for grandma Austria" is a sublimation of a certain disappointment in Ukrainian realities. ${ }^{6}$ This connection with contemporary conditions in Ukraine is indisputable. But what kind of connection is that? Participants and observers alike tried to create the impression that this celebration was the expression of a more general nostalgic sentiment, of the longing for the bygone "golden days," so natural in this part of Ukraine and resembling similar sentiments for the Russian Empire in the east. Those reporting on the event noticed that in L'viv this 
kind of action did not seem surprising in view of the general nostalgic mood expressed in café menus, decorations and names.

But let's not allow ourselves to be taken in by these statements. Participation in the celebration itself was limited to exclusively "elite" circles, something which was also acknowledged by the organizers. The "general public" does not patronize cafés and restaurants where this kind of nostalgia for the lost nineteenth century is expressed because they are too expensive. Actually most of the cafés and restaurants trying to capitalize on this retro atmosphere, utilize more artifacts and images from the interwar Polish period than from the Habsburg past. Even those making references to popular sentiment could not point to the portraits of Franz Joseph anywhere else than over their own desks. The popularity of the Emperor and of the Empire in L'viv cannot be compared even with Ukraine's closest neighbors, let's say Polish Galicia, where the presence of the Habsburg past is much more visible. This emphasis on popular sentiment serves to hide the fact that the event has much more to do with the construction of a visible Galician past than with some real continuity from that past, and is part of the project to legitimize itself through the past.

Now I would like to cite an account of the celebration from the newspaper Postup which has for a few years been promoting the idea of the special status of Ukrainian Galicia in its relationships with the rest of Ukraine and which can be seen as the most important medial protogonist of these ideas. The article in that newspaper refers to Franz Joseph I as "Him" (with a capital H), mentions "His glorious times," and states that our dream to meet both of them (Franz and his times) will be materialized in the form of a monument:

We associate the eternal dreams of L'viv's inhabitants to create a city in which we would like to live precisely with the time of the Most Enlightened. It does not matter that in his presentation, Kost' Bondarenko, Director of the Center for Political Research, described the Emperor as a 'brilliant mediocrity'. For us he remains a standard of the greatest prosperity, heavenly flight and the unsurpassed greatness of spirit. At the same time, Franz Joseph remains for us a relative, a member of our family, a good grandfather, whose portrait, as pointed out by Taras Batenko, 'would always stand over our desks."

In the context of particularly this newspaper this quote does not look as surprising as it would on the pages of the official or semi-official press, or those affiliated with the political parties. Postup has also published several articles on Galician history which obviously go beyond the usual interest in local history common for regional newspapers. As an example, we can take the article on Mikołaj Ziblikiewicz, the headline of which is "Ruthenian by birth and Pole by nationality. Mikołaj Ziblikiewicz - one of the leading figures in nineteenth century Galician politics," in which this Greek Catholic one-time mayor of Kraków and enemy of the Ukrainian national movement is depicted with sympathy. ${ }^{8}$ 
I guess it is quite obvious that we are dealing here with something larger than just "popular sentiments," with something that is deliberately provocative, with something that tends both to exaggerate and to label. We are dealing with speaking "on behalf of," with attempts to inscribe that pose as reading, with, I would say, a typical identity project. The monument is presented as a realization; people are honoring someone and something that is already there. Franz Joseph stands for the old Galicia, for the Galicia of the golden age "when we also belonged to Europe."

Failure on the part of the current Ukrainian state is also involved here, which is usually referred to as "the disappointment in realities." Phrases like permanent economic crisis, political impotence, and corrupt and irresponsible government have become clichés in journalistic discourse. But this failure has several aspects. The shifting alliances of those in power are difficult to trace and to analyze. The phrase "party of power" has become a standard phrase used by both journalists and political scientists. We could say that the opposition "the power-block versus the people" is an obvious and consensually recognized factor of political life in Ukraine. But is this the only aspect of Galician dissatisfaction with the regime? At least in the strategies of the proponents of Galician regionalism, we do not see attempts to mobilize people against this power-block, to build up a political alliance; we do not see detailed projects of economic reforms. It seems that Galician regionalism signals other things.

The projected monument can be seen as a signifier not only of disappointment in "realities" but also of disappointment in the more general Ukrainian project. It is an attempt to revise the whole construction of the Ukrainian nation, the way it was imagined in the nineteenth century. It is difficult to characterize the current Ukrainian state as a nation-state - it does not "nationalize": Ukrainian identity is still unstable, Ukrainian citizenship is not much of an asset, not only economic but also cultural capital flows are not regulated by the Ukrainian borders. To paraphrase Roman Szporluk, it is not clear if the Ukrainian state will provide better access to the world. ${ }^{10}$

I think that this growing dissatisfaction with the Ukrainian identity is the greatest resource of Galician regionalism. But this aspect, the non-Ukrainianness of the Ukrainian state does not figure prominently in the discourse of Galician regionalism, partly because this aspect has already been appropriated by the rhetoric of the nationalist parties, and partly because of the nature of the new Galician project. The distinctive feature of the discourse of Galician regionalism is "Central Europe." In terms of the political criticism of the Ukrainian state expressed by Galician regionalism, this state as a whole is too slow, or not at all eager to enter this particular space, in which Galicia shares while the rest of Ukraine does not. I would argue that "Central Europe" in this case covers Galicia's longing for the modern nation-state that contemporary Ukraine is 
failing to consolidate (in the address cited at the beginning of the paper Central Europe is imagined as a circle of free nations).

My position is that instead of speaking about popular sentiments and analyzing the assumed distinctness of Galicians (or, at least, of L'viv's population) vis-à-vis other Ukrainians, we should look into how these differences have been created and how this new Galician identity has been constructed in close connection with the symbol of "Central Europe." Political and economic factors play a huge role but these "factors" are accessible only as cultural manifestations within a clearly defined cultural field, represented in a certain way, appropriated and negotiated. These "factors" do not function independently of the cultural field in which they are placed. These "factors" do not constitute an independent referent, providing satisfactory answers in themselves. We should try to decipher how these "factors" serve as rhetorical strategies within the general discourse, and how they constitute the rules for constructing the referents we encounter in this discourse.

Like any other any attempt to create a distinctive and more suitable (or, as the proponents of this movement would say, to uncover the real) identity, this modern Galician movement produces its own canon, which shows how Central European culture, which is the code in which these things are mediated, is created and how it signifies. A striking example of these attempts at codification is to be found in the ninth issue of $J i$ journal published in 1997, the issue of a Cultural Studies (kul'turolohichnyi) journal dedicated to Central Europe. Let's look at the contributors to this Central European issue. We have poets, prose writers, political scientists, Otto von Habsburg, literary critics and philosophers (for the complete list of the authors see Appendix A). To gather all these texts in one issue makes very little sense unless we understand that it creates its own "order of things," and targets intellectuals to whom such an order appeals. Contributors from "Central Europe" come from Austria, the Czech Republic, Poland and Ukrainian Galicia; the gender ratio is 34 men to 3 women. The underlying myth is a common set of high culture products, knowledge of which defines Central Europe. A certain mode of cultural production determines the existence of Central Europe and indicates the eastern border of that space. This is Kundera's Central Europe with an emphasis on the Ukrainian parts of the Habsburg Empire. It is very important to note that the issue codifies a larger space, of which Galicia is an integral part. ${ }^{11}$

I do not want to create the impression that all this Galician business is just a pig-headed attempt to create one more outpost of "Europe." I believe that there is much more to it. I must say that the perspective of Galician regionalism is actually very appealing because it is a counter-hegemonic project (if we assume that hegemony is a useful term for the description of the cultural politics in contemporary Ukraine), probably the only project in contemporary Ukraine 
that pays attention to the identity politics involved and provides with us an opportunity to revise existing approaches which neglect a cultural perspective on the processes in contemporary Ukraine. Sometimes it makes me feel that Galician is, in fact, the only "real" regionalism in contemporary Ukraine.

Because I do not believe in the continuity of culture and in history as a flow of events that naturally sorts things out, I will be looking here at historical aspects of Galician regionalism, which does not mean that a spatial program for Galicia or a geography of this new regionalism is unproblematic. The articulation of a Habsburg heritage forces us to put together Galicia, Bukovina and Transcarpathia, and not pay attention to the fact that the latter "experienced" the Habsburg rule very differently from the former two. At the same time, Volyn,' which in many aspects is quite close to Galicia, which shared with the latter the "experience" of being part of the interwar Polish state, and which for the average citizen of Ukraine or the former Soviet Union (who would never use a word like Halychyna (Galicia)) is definitely part of "Western Ukraine," is excluded from this space. But in the narratives of modern identity, space is constructed through historical time, and the historical narratives surrounding this Galician revival are very revealing of its formation and its problems.

\section{H I S T O R Y}

The old Emperor stands as a sign of so-called "historical experience," a sign which can be used for symbols with totally opposite meanings, depending on how "historical experience" is constructed in any given semiotic system. But to make a truth claim, even the systems with opposite meanings of this symbol have to share a certain view of historical experience. One of the key features of this experience is, of course, the fact that it has nothing to do with individual experience. Historical experience is understood as forms created historically and difficult to dissolve. As it was stated in the article describing the celebration dedicated to Franz Joseph I, "the contemporary Galician, Bukovinian, and Transcarpatian thinks that way - during the time of Franz Joseph I, L'viv, IvanoFrankivs'k, Chernivtsi, and Uzhhorod formed their original face and now they are being actively destroyed." ${ }^{\prime 2}$

On one hand, those telling this particular version of Ukrainian Galician history are fully aware of their connection with the present. Taras Batenko, for example, writes that:

Even now, the generation which is able to form its opinion of Austria only on the basis of proverbs and reprints, feels a certain nostalgia for these good old days of sometimes never fully realized hopes but tireless and self-sacrificing work. This nostalgia is supported by the portrait of Franz Joseph. ${ }^{13}$ 
But the present in Batenko's case only encourages us to ask certain questions and does not influence answers. Later Taras Batenko affirms the reality of the properties he attributes to the period, such as this pragmatic "tireless and selfsacrificing work" which is not only symbolized by the Emperor but vigorously attributed to him. While the pragmatic work's association with the person of the Emperor becomes a social fact, the opposition between this image and the flamboyant and irrational actions of the Other $\left(20^{\text {th }}\right.$ century??, Eastern Europe??, Eastern Ukraine??) is hidden under the facade of historical reference.

Taras Batenko's presentation was published in L'viv regional council's official newspaper. Taras Batenko, who did his undergraduate in history and his Ph.D. in Political Science in L'viv, specialized in nineteenth century Habsburg politics; therefore it is surprising to find in his presentation statements like: “... democratic centralism, as it is known, he [Franz Joseph I] replaced with a liberal parliamentary regime, then tightened the screws once more, and loosened them again introducing significant liberal reforms in 1860." He mentions "democratic centralism" more than once; as far as I know, no account of Austrian history prior to 1860 does likewise. ${ }^{14}$

It is interesting that Kost' Bondarenko's more "sober" talk has not been published, whereas Taras Batenko's historical outburst has. Both speakers claim to arrive at their views by engaging with historical material which opened their eyes to the "real" position of Galicia, its "real" cultural face. That is where they cease to be present-oriented. They claim to find "real" history, one that formed the place in which they live, more than any other history.

The number of historical articles and monographs on Ukrainian Galicia grew with an amazing speed during the 1990s. All of them in one way or another contribute to the construction of Galician identity but I will look at a particularly recent piece, one directly connected with the events, people and media I have been discussing. An example of serious historical discourse which wholeheartedly supported this construction and seemed in touch with public debate appeared in Postup (no surprise here) on May 30, 200o. It was the full version of a paper delivered by Vasyl' Rasevych at a seminar of the Ji journal on May 11, 200o. The article is entitled "Austrian Ukrainians between National Idea and Imperial Loyalty."

The article begins with a statement about the possible political consequences of research on this topic: "Many Ukrainian politicians will easily discern in this topic a danger to the independence and unity of the Ukrainian state." Is this a confession of a partisan of the Galician revival? Not exactly, because his views are based on the uncovering of the real past against the ideological schemata that have shaped and still influence research on Ukrainian history. Rasevych states that many contemporary Ukrainian historians are not that different from the historians of the Soviet time; they accepted the new ideological scheme of 
Ukrainian nationalism just as they worked in the older Soviet Marxist style. The author himself arrived at the ideas expressed in this presentation after working on the history of the Ukrainian National Democratic Party in Galicia. While working on the project, he discovered that the Ukrainian parties in Galicia had before 1918 never thought about the creation of an independent Ukraine (they merely claimed cultural unity with other Ukrainians in the Russian Empire), and he explains that the difference between Galician and Russian Ukraine was obvious for the Galician Ukrainians. World War I separated Ukrainians on both sides of the border even more than they were separated before. That is why the Austrian Ukrainians proclaimed a Ukrainian state in the Austrian Empire and why they did not want to join the "Greater Ukraine," when the Western Ukrainian Popular Republic was created in November 1918.

It is highly symptomatic of modern identities to privilege certain chronotopes and to suppress temporal reorganizations of space. That is why Vasyl' Rasevych omits the question of which kind of Ukrainian state was in the Russian Ukraine in November 1918, and the debates surrounding the union of the two states. He prefers to explain the behavior of the Western Ukrainian state through the differences between the Austrian and Russian Empires. (For the summary of this point from his own paper see Appendix B.) But the problem is that when he discusses differences, he accepts the usual schema of Ukrainian history. Many of the differences he articulates can be found in Shlemkevych's Halychanstvo; others appeared in interwar publications dealing with the problems of the defeat and tensions between the two states. The new thing is that while in these older texts the differences were presented as written onto the singular material of the Ukrainian nation with the same texture, a texture that was more important than fractures in it, in Rasevych's narrative this common texture of the nation disappears and fractures are absolutized. Again, Vasyl' Rasevych tries to define the properties of Galician Ukraine - conservatism, parliamentary democracy, lawyers as political leaders, national consciousness -, the properties whose traces will prove the existence of the autonomous subject who possesses them. In the same way as all projects that aim to become dominant, he does not attribute positive or independent properties to the adversary; the "Other" is defined solely through negation. His discussion of encounters between the two Ukraines proves this: Eastern intellectuals were not able to understand Galicia (Drahomanov), Eastern symbols could not be appropriated on Galician soil (Cossack ideal).

As you see, all his points are based more on the assumed explicit opposition between Galicia and the rest of Ukraine than on any claims to engage with the historical sources. He explains the behavior of the Western Ukrainian state through the difference between the realities of the Austrian and Russian Empires. 
I will now turn to a Polish historian who recently published a book on Ukrainian-Polish relations to show how Rasevych's construction mirrors Partacz's, substituting Ukrainians with Eastern Ukrainians and Poles with Galician Ukrainians. Actually, two sections from Partacz's book (see Appendix C) describe the object of Rasevych's research, precisely Ukrainian national democracy, in a totally different light. This does not mean that I like Partacz's book; I actually believe that Partacz applies to the relations between Poles and Ukrainians the procedure Rasevych used with Galicians and Eastern Ukrainians. When you read Polish sources from the beginning of the 2oth century, you have the impression that they attribute to the Galician Ukrainians all the "negative" properties - like social radicalism, rhetoric instead of pragmatism, inciting popular sentiments, unfitness for parliamentary procedures - which Rasevych attributes to the Russian Ukraine. ${ }^{15}$

This problem, that historians are somehow inclined to see regions like Central Europe in terms of continuity and a stable identity informed by absolutized "historical experience," is not limited to Ukrainian history. The vision of history as a flow of events that determines boundaries and not of history as a contemporary and political discourse still informs much historical writing. Allow me to cite a passage from Aleksei Miller's article on the concept of Central Europe:

It is important that this region has a certain historically conditioned specificity, which can be seen on all levels - political, social, and cultural, and which typologically differentiates societies that belong to the region from their neighbors. In each chronological sample, this specificity can be changed, but, I repeat, it is historically determined. For a historian the most important factor is the socio-cultural proximity, similarity of social and power structures as well as ways of their evolution, similarity of the cultural tradition and of mentality.

Miller's conclusion is that we must distinguish between this real historical Central Europe and its political constructions. ${ }^{16}$

\section{AN ALTERNATIVE}

I am looking for an alternative to Galicia and Central Europe as constructed in these narratives of Galician regionalism not because I perceive them as a danger to my Ukrainian identity; it is the reification of Galicia and the essentialism of these narratives that I consider dangerous. The function of the symbol "Central European Culture" as it presented itself at the anniversary celebrations of Franz Joseph I in L'viv last year is highly normative; this codified system is an exclusive and totalizing space of identity. Identity is built on oppositions: the border works towards closure and the identity is firmly anchored in historical experience. Because of this, a new Galicia can potentially become a repressive mechanism, which marginalizes all those who do not share this imagined "Cen- 
tral European Culture." While resistance to the Ukrainian "realities" is believed to result only in a form of counter-hegemonic discourse, i.e. Galician regionalism, this counter-hegemonic project has the potential to become one of domination.

The question right now is neither about Galicia nor Ukraine. One of the points, on which I believe this construction rests, is that Galicia is more Ukrainian than the rest of Ukraine. Right now the idea of a separate Galician state is not in the public discourse. But this does not make this project less important. The question is what kind of Galicia, what kind of Ukraine and what kind of Central Europe. At the very same time when the $170^{\text {th }}$ anniversary of Emperor Franz Joseph was being celebrated in L'viv, there took place across the border, in a small Polish town, an international festival dedicated to the good soldier Šwejk. Admirers of Hašek and his famous novel gathered at this festival but no Ukrainian or Galician delegations attended, despite the fact that in the book Šwejk's odyssey ends in Ukrainian Galicia, near the small town of Felshtyn in the later Sambir district.

The new cultural movement I have been attempting to describe is trying to resist the dominant tendencies of the Ukrainian state, but in this attempt it is resorting to the old methods of historical construction. Trying to overthrow the singular narrative of Ukrainian national history, its historians are creating a similarly singular version of Galician Ukrainian history, culture, etc. Trying to oppose a strong Ukrainian state and to create an independent public sphere in Galicia, intellectuals at the same time open this public sphere only to a certain kind of debate, to a certain kind of politics, and envision a Galician identity which is (from my point of view) very problematic.

Is there any way to transform this still somehow sympathetic project into something different, something able to accommodate different kinds of history and to redefine Central Europe and Galicia while avoiding the construction of a homogenous cultural space enclosed by the boundaries of identity?

Iurii Andrukhovych is a name one often runs across in the discussions, such as during the seminar dedicated to the anniversary celebrations of Franz Joseph's birthday. For example, it was said that "The theorization of this nostalgia of Western Ukrainians for the times of Austria-Hungary (which they know only from their grandparents' stories), we can find in the several essays by Iurii Andrukhovych in his latest book Disorientation in place. Attempts..."17 While I agree that Andrukhovych in these essays theorizes Galicia, Central Europe, and Ukraine - the spaces of his poetry and prose -, I also believe that he is too often misread by his interpreters, especially with respect to his views on Galicia and Central Europe.

Let's start with temporality, which, paradoxically, is missing from the narratives of the historians constructing this Ukrainian Galicia. Unlike the Galicia of 
the serious historians, which is still intact, Andrukhovych's Galicia is no longer there. About the quintessential Galician city of Stanislaviv, he writes: "today it is almost non-existent." The past has passed, it is lost, his Galicia is the product of imagination. He started imagining it when he came to study in L'viv, he constructed it in opposition to the "realities" of the city, with its bee-hive-like apartment-blocks dominated by the newcomers from the countryside, and by Soviet mass culture. His Galicia, with its Polish Counts and Barons, its balls, its Yiddish speaking Jews, Ukrainian peasants unspoilt by industrialization (or Sovietization), has nothing in common with the contemporary Western Ukraine except that it's the same territory. His Galicia was possible only because of the Soviet system in and against which it was constructed.

In claiming that Andrukhovych has been misread, I am not saying that I do not see any problems with his narratives. There is, especially in the earlier essays, an elitism, a nostalgia for a high culture that has disappeared, and simplifying statements about cultures and people, but even in these earlier essays, there is also irony and self-irony. Only those totally charmed by his style or those expecting to find only an apologia of Galicia will not notice it. He makes "points" about what Galicia did for Ukrainian culture but at the end he says that, probably, some "points" could have been made differently, even all of them, because if something is left from this Galicia, it cannot be caught, and if it is caught, it is no longer something left. Moreover, in his later essays, the image of his Galicia changes significantly.

His essay on L'viv starts with the quotation that on the spot where the Carpathian mountains now stand, millions years ago there was a sea. And now, L'viv is positioned on the watershed which, in fact, should be viewed not as a watershed but a joint. The sea is gone and L'viv suffers from a lack of water supplies. This is an allegory of culture. With all the talk about multiculturalism, especially in the context of Central Europe, the most important thing about that multiculturalism is that it belong to the past. That is why it is so easy to talk about it now. Those who see the Habsburg Empire as a multicultural society can do so easily because this multiculturalism is pacified by the framework of the contemporary state borders. Discussing the multiculturalism of days gone by is a handy way for not discussing the new multicultural problems of Central Europe, such as those connected with migration and racism. That is why Andrukhovych says that "Idyllic and painless multilayerdness of cultures is a myth and I am not sure that this myth is harmless."18

Andrukhovych's Europe, especially Western Europe, the real one, the one not discussed much in this Galician regionalism, is not as innocent and idyllic as those would have it who state that Galicia belongs to the European imagination. Andrukhovych is able to go there because his visa to Germany was signed by Rainer Maria Rilke whose poems he was translating; the knowledge of high 
culture, and participation in it, gave him access to this materialized paradise. Even there he is not quite happy with living in a comfortable villa close to $\mathrm{Mu}$ nich; the paradise does not substitute for his imagined Galicia. In Europe he is searching for the carnival but carnival escapes him or rather he cannot catch up with it. His essays stress the discrepancy between Europe imagined by Europeans and Europe imagined in Galicia: "the point is that we are happy in our own ways. And for that we should be paid a tribute - we are happy because we do not know anything about the world."19

And this is not just the matter of Galicia not knowing Europe, it is also about Europe's attitude towards places like Galicia. In the essay "After the Ball," he describes this as follows:

They were returning from the ball, majestically, in pairs, elder and younger, most respected 'Western people,' they flew not paying any attention to us, and the only thing that could attract their attention was falling down on all fours, barking desperately, and biting someone's pant leg. ${ }^{20}$

In "Is the Empire Dead?" the Habsburg mausoleum (Kaisergruft) just off the Kärntnerstrasse is described as the ideal place for the historian. All the rulers, periods and places are put in order and classified. But he could not stay there for long. The Kärntnerstrasse itself was much more interesting than the Empire. This real piece of Europe is more interesting than our attempts to construct an ideal one. Another essay on Vienna, the capital of Central Europe, is entitled "The Effects of the Gallery." The author went to see "Don Giovanni" at the Staatsoper and discovered that it was only possible to get a ticket for the "standing room" section (the Stehplatz). These "standing seats" are practically infinite, everyone can be accommodated there. He is impressed not just by the music but even more by the line to get in, by the lines controlled by personnel, with armylike discipline, their coordinated movements, trained bodies and words of command: "two at once," "do not spread out", "schnell." And only then Opera, Opera after a "concentration camp." ${ }^{21}$

Let's go back to the first essay in the collection, "Erts-herts-perts." On the one hand, the Habsburg Monarchy is praised for things for which Ukrainians should be grateful to this Empire, such as the Ukrainian language, the touch of European culture. On the other hand, this Empire is an encounter, and not an enclosed space, an encounter which is not a belonging. The title of this essay, the nonsensical "erts-herts-perts," is the answer of a Galician peasant recruit requested to repeat the rank and name of his superior, "Erzherzog Albert von Toskana." According to Andrukhovych, this is the "diagnosis" of "everything we do," of Ukraine and of Ukrainian. It is a mockery and dislocation of meaning. It is a mockery not just of the Empire but of Ukrainian attempts to belong to Europe as well. But the imagined belonging of Ukrainians to the European space is not important for Andrukhovych because "the most important thing in my 
project is the evening wind, the flight of quiet angels, which adds to everything an unstable, slightly disheveled appearance." ${ }^{22}$

In the last essay of the collection, Andrukhovych develops the idea of Galicia as a marginal and marginalized space, which does not mesh well with the established construction of the Ukrainian nation (see Appendix D). But it does not mesh well with the imagined Central European space either. Andrukhovych stresses Galicia's hybrid nature and is obviously responding to attempts to codify this Galician space in the ways I have discussed. Andrukhovych is against the essentialization of differences; differences are always in the process of being made, they are always used and appropriated. This kind of view allows Galicia to enter the discursive field while remaining a minority discourse. Andrukhovych's Galicia recognizes the minority position as legitimate for articulation and provides an opportunity to avoid this striving to become dominant.

While Disorientation in place is about space, in a more recent article, "Central-Eastern Revision," Andrukhovych tackles time. ${ }^{23}$ There is a fascination with the past, an addiction to the past, in his part of the world, which he shares: "since early childhood I have been attracted by ruins." Andrukhovych defends this kind of historical consciousness but stresses that his ruins are different from those of many other historians: "it could be just the smell and it could have nothing to do with Geist." ${ }^{24}$

Andrukhovych starts with his personal history. He pieces together his personal narratives, memories from his youth, memories of his grandparents and parents. By doing so he shows that this is not about recalling - his personal history is about constructing. He shows how Central Europe is constructed in his case and implies that larger histories use similar mnemonic techniques. History is constructed but it cannot be controlled; because of its memory-like nature history always remains a journey.

His family's journey begins with a Sudeten German who arrives in Galicia. Then there is his grandfather's father who gets run over by a streetcar in Chicago; his wife goes there to search for the husband, gets rich (by Galician standards) and returns. Left alone, his grandfather travels west to reach the "Great Water" which took his parents; the "great water" he reaches is actually the Danube: "The little boy is contemplating the river. Beyond the river the New World begins. On the other side of the Danube lies America, in fact, the future, on the other side of the Danube everything that, with time, will come true (or will not come true)." Later, the grandfather, now a former Austrian officer, fights in the ranks of the Ukrainian Galician Army in 1918-1919 and dies in 1944, killed on a train by the airplane he and other volunteers had taken on their way to join the Ukrainian army which had been created by the Nazis to fight on the Eastern front: "His devilish ally was slowly losing the war, but like thousands of optimists he had not given up the hope that in the result of the final collision be- 
tween the brown and red Satan it would possible to liberate the country." ${ }^{25}$ It is a typical Central European death which Andrukhovych characterizes as a "prison or camp death and a collective one." He dies in the train and so his Central European journey ends, a journey which is always an escape.

A key figure in the essay is Andrukhovych's father. His Central European journey took place in 1944-1945. He is the one traveling as a child in a train of refugees from Galicia, a train which is an ideal society, having its own lawyers who rule, artists who perform, boy scouts who exercise and so on. And this society moves west. The train is a symbol, a tool of modernity, changing its connotation from the first trains of progress to the trains heading for Auschwitz. The trip ends in Vienna, and his father discovers his own "great water" but he did arrive there in search of it, as had been the case with the grandfather. He had been brought there by the "Central European fear," a fear that swings between two anxieties: "The Germans are coming, the Russians are coming." Propelled by fear, the train with his father arrives at the banks of the Danube and there the father discovers a perfect thing, the Riesenrad in the Prater. This ferris wheel is something Andrukhovych could not understand: when he was leaving for a conference in Vienna his father told him that he must see this ferris wheel in the Prater: "I wanted to answer: 'why in the hell do I, with my 37 years, need this Riesenrad, but, thank God, I did not."

His father has no other connection with the Habsburg Empire and with Vienna except this ferris wheel, and Andrukhovych realizes the importance of the wheel only when his father dies. The father who had grown up on Westerns in interwar Poland, and who had enriched his vocabulary during his service in the Soviet Army. This father stands for a different kind of Central Europe, defined not through "belonging" but through its "in-between" position. Just like that Central Europe, Andrukhovych's Galicia is shaped by an acute awareness of modernity. For him, Galicia is not only after totalitarianism, it is a place still very sensitive to any kind of totalitarianism. "Russians go, Germans go" and "Central European fear" in Andrukhovych's essay go beyond a geopolitical conceptualization of Central Europe between two great powers. His view is that totalitarianism is not as much past as it is a series of projects that are still possible. Some critics wonder why, despite all his postmodernity, quite often for Andrukhovych "white is white, black is black and red is red." I would say this is because "postmodern" for him means this acute awareness of the consequences of certain projects and the imperative to react to them. To the projects trying to stop the ferris wheel of the Central European space.

If we go back to history, Andrukhovych says, "Fortunately I live in the part of the world where the past is terribly important. Some call it rootedness and some - obsession. I do not know what to call it: it just that this part of the world has too many ruins, too many skeletons under one's feet. Fortunately I cannot 
get rid of that... I'm worth nothing without my memory..." ${ }^{28}$ For him this attitude to the past and this work with memory retains its critical potential because histories are not only about remembering but even more about forgetting. Andrukhovych's history is an alternative to the linear time of Enlightenment, to the time that arrests memories and anchors identities.

APPENDIX A

Authors represented in Ji journal, issue 9, 1997.

Antonin Lijem

Edgar Morin

Vaclav Czihak

SłavomirWiatr

Otto von Habsburg

Claus Leggewie

Józef Darski

Stefan Zweig

Alexander Roda Roda

Andrzej Braun

Paul Celan

Ivan Holoversa

Taras Vozniak

Ernst Jandl

Taras Luchuk

Larysa Tsybenko

Viktor Moiseienko

Ivan Senatovych

Iurii Izdryk

Erhard Busek

Urs Al'termatt

Andrzej Wincenc

Ivan Krushel'nyts'kyi

Rose Ausländer

Krzysztof Czyżewski

Robert Musil

Igor' Klekh

Fritz Herzmanowski-Orlando

Georg Trakl

Rainer Maria Rilke

Hans Georg Gadamer

Helmut Eizendle 
Khrystyna Nazarkevych

Ivan Luchuk

Bruno Schulz

\section{APPENDIX B}

From Vasyl' Rasevych, "Avstriis'ki ukraintsi mizh natsional'noiu ideieiu i impers'koiu loial'nistiu" (Austrian Ukrainians Between the National Idea and Imperial Loyalty), paper presented at the seminar of $J i$ journal, May 11, 2000.

We can assume a "criminal" thought that the differences between the Austrian and Russian Ukrainians, and not tactical considerations, were the main obstacle [to unification in 1918]. We can provisionally divide the factors that contributed to these differences into the following groups:

a) those determined by the peculiarities of the process of national self-identification among Austrian-Ukrainians

b) those determined by the peculiarities of the social structure and political leadership.

Among the factors in the first category we can put the following:

* The political modernization of Austrian Ukrainians took place under the conditions of a constitutional state while Russian Ukrainians were elected to the Council for the first time in 1906. This means that they had almost no experience of legal and constitutional work.

* The process of national self-identification among Austrian-Ukrainians was intrinsic and not unidirectional. Apart from the problems of self-identification, there were difficulties with the acceptance of the names "Ukraine" and "Ukrainian," which were new for Galicia and Bukovina.

* The idea of a united and independent Ukraine adopted by Ukrainians in Austria was that of a nation to be realized in a distant future, rather than during their lifetimes. This could be explained by the discontinuity of the state tradition which transformed the idea of unification into a purely theoretical demand which did not always work out in practice and did not produce the expected results during the process of national mobilization.

* The differences in the national characters of the Austrian and Dnieper Ukrainians did nothing to contribute to the assertion of an ideology of unification. Particularly, we are talking about differences in the historical tradition (the experience of living in different state-political formations), the mental and confessional division between Greek-Catholic and Orthodox (including the whole complex of stereotypical images of the other), a lack of information about the other and of cultural exchange caused by the existence of the state border, and totally different policies of these states regarding the national question. All these differences were caused by the fact that Ukrainians entered the process of mod- 
ern political nation formation while remaining in two totally different political systems, which were also different mentally.

On the factors in the second category:

* Politically, Austrian Ukrainians matured under the conditions of a constitutional monarchy. There were no persecutions by the Austrian authorities based on the principles of nationalism. The availability of the parliamentary tribune and a comparatively liberal law on the freedom of assembly provided an opportunity to conduct political struggles by legal means.

* The political leadership of the Austrian Ukrainians consisted of up to $80 \%$ lawyers, which is why all their activities were dominated by the principle of legalism. At the same time, in the Russian Empire the prohibition of a Ukrainian movement in any form led to the formation of a group of activists inclined to illegal action. Because of the persecutions of the Ukrainian movement in the Russian state and the comparatively favorable conditions for the national development in the Austrian one, the only legitimate source of power for the Galician Ukrainians was the Habsburg state.

* The conservatism of the Ukrainian Galician environment was marked by the significant participation of the Greek Catholic clergy in the political process, while in the Dnieper Ukraine that movement had leftist leanings.

* The fact that Ukrainians were living in the Austrian state created a numerically small but influential patriotic group, whose political credo can be described as schwarzgelb [monarchist]. These were the patriots of the Habsburg state; for them loyalty to the ruling dynasty was of utmost importance and determined their identity to a significant extent.

* Simultaneously, the Ukrainian national movement in the Russian empire did not have the characteristics of a mass movement, while in the Austrian part the opposite was true.

* The social structure of the Ukrainian society in Austria was more developed that in Russia.

* In the Habsburg Empire, national mobilization penetrated all levels of Ukrainian society, while in Russia it was limited to the narrow circle of the Ukrainian intelligentsia.

A P PENDIX C

From Partacz, Czesław. Ot Badeniego do Potockiego. Stosunki polsko-ukraińskie w latach 1888-19o8. Toruń, 1996:

"A new turmoil at the university was caused by the so-called whistling protest of the Ukrainian deputies on Hutsul fifes during which the Slovenian dep- 
uty Benkowič was severely wounded by L. Bachyns'kyi. This escapade, unheard of even in the Austrian parliament, caused general indignation in the Chamber. The indignation was even greater because the Ukrainians were generally suspected of having prepared this strange obstruction for quite some time. This general indignation was reinforced by worries about destabilization of the parliament. Romanchuk and Vasyl'ko persuaded the Chamber's president not to hand Bachyns'kyi over to the procurator with difficulty. Despite this indignation, Dilo [the daily of the Ukrainian national democracy movement] continued to provoke, suggesting that the parliament had been changed into a display of the eternal scandals and Galicia into Macedonia" (217).

"Among the national-populists, extremist and radical groups prevailed. The moderates Olesnyts'kyi or Vasyl'ko counted less and less in internal political games. Each time, a more radical tone was set in the Ukrainian press, and changes in provincial and state politics towards more radical tactics were encouraged. Svoboda encouraged expelling Polish and Russian occupants from Ukrainian soil. One of the most active local politicans of the UNDP, Rev. S. Onyshkevych, called in Dilo for "courage and warrior skills." Ievhen Olesnyts'kyi tried to prove that parlamentary obstruction was the only way to achieve numerous goals. After the meeting of the Ukrainian deputies to the State Council, which took place in L'viv on March 6, 1908, there was no doubt that deputies with extremist views had gained the upper hand" (221).

\section{APPENDIX D}

From Andrukhovych, Iurii. "Chas i mistse, abo moia ostannia terytoriia" (Time and Place of My Last Territory). Dezoriientatsiia na mistsevosti. Sproby. IvanoFrankivs'k: "Lileia-NV." 118-119.

There are real regions, integral even in their desolation and ugliness. Galicia, in its turn, is thoroughly artificial, obviously cobbled together with pseudo-historical fantasies and political intrigues. Those who state that Galicia is merely a one hundred and fifty year-old invention of a few Austrian ministers are a thousand times right. A sweetly mannerist idée fixe of certain deeply conspiratorial strategists who at a certain point set a chimerical goal to extend Europe a little bit further east. The outcome was not a Europe but a kind of buffer, a sort of "sanitary zone"...

Galicia is a non-Ukraine, some kind of geographical makeweight, Polish hallucination. Galicia is thoroughly dummy and doll-like, puffed up, in everything and everywhere trying to impose upon Ukraine its non-Ukrainian will, that has been infused in dark Zionist laboratories. Galicia is deprived of epic, this is the place where from time immemorial the anecdote reigns, and base ones at 
that. To be more precise, this is a rootless space, fit only for nomadic tribes hence all those Armenians, Gypsies, Karaims and Hassids. Galicia is a Philistine motherland of Freemasonry and Marxism. Galicia is mischievous and false, it is a stinking menagerie overfilled with serpents and chimeras, Galicia is good only for mutants like Bruno Schulz or all these petty Stanislaviv Kafkas, and if you are not a mutant but let's say a Stefanyk, the only thing left to you is the inevitable taking to drink in the first available Rusiv. ...

The ironic tone fits perfectly here. All Galicia is ironic and immoral; that is why this eternal tergiversation and being accommodating, permanent Uniate-ness, children sold to America. Galicia is ostentatious and superficial, like plated mannequins; ridiculous shuffling in all directions, kissing hands and door-knobs with a preserved peasant smack; Galicia is endless and drowsy, boringly hackneyed conversations about Europe, Europa, Ouropa, about "we are also in Europe," while the whole printed production of Galicia can be accommodated in the single mid-sized L'viv suitcase...

\section{NOTES}

“A tym chasom... Cherez rik u L'vovi vstanovliat' pam'iatnyk Frantsu Iosyfu I. A na razi sviatkuiut' ioho urodyny." Vysokyi zamok (August 19, 200o).

\section{Ibid.}

On the one hand, accusations were made against the violent and intolerant Russian popculture dominating the market and oppressing indigenous Ukrainian cultural production, on the other - against the "Ukrainizing" policy of the local authorities who administratively suppress Russian culture and the rights of the Russian minority in general.

“A tym chasom... Cherez rik u L'vovi vstanovliat' pam'iatnyk Frantsu Iosyfu I. A na razi sviatkuiut' ioho urodyny." Vysokyi zamok (August 19, 200o).

5 Taras Batenko. "Frants Iosyf na biurku." Vysokyi zamok (August 19, 200o).

Volodymyr Paliiv. “Tuha za Evropeis'koiu Ukrainoiu.” Polityka i kul'tura 31(66) (2000).

Liubko Petrenko. "I my dizhdemosia tsisaria. Urodyny." Postup (August 19-20, 200o).

Ivan Hor. "Rodom rusyn, za natsional'nistiu poliak. Mykolai Zyblikevych - odna z chil'nykh fihur halyts'koi polityky XIX stolittia." Postup (August 15, 200o).

9 That is why all the prognoses about Ukraine's future based on the idea of the "nationalizing state" did not work. As an example see Aleksei Miller. "Ukraina kak natsionaliziruiushcheesia gosudarstvo." Pro et Contra tom 2 (vesna 1997).

Roman Szporluk, "Ukraine: From an Imperial Periphery to a Sovereign State," Daedalus 126.3 (Summer 1997), 113.

The mechanics are similar to those in the case with nationalism, which cannot exist by itself; as any other modern project the Galician regional project must place itself inside of the larger world order.

Paliiv. "Tuha za Evropeis'koiu Ukrainoiu. cited in Paliiv. "Tuha za Evropeis'koiu Ukrainoiu."

"A tym chasom... Cherez rik u L'vovi vstanovliat' pam'iatnyk Frantsu Iosyfu I. A na razi sviatkuiut' ioho urodyny." Vysokyi zamok (August 19, 200o). 
15 Ignacy Winiarski. Rusini w Radzie pañstwa. 1907-1908, Nasze sprawy na Rusi. III. Lwów: Z drukarni udzia ${ }^{3}$ owej, 1909.

16 Aleksei Miller. “Ob istorii kontseptsii 'Tsentral'naia Evropa.” Tsentral'naia Evropa kak istoricheskii region, ed. Aleksei Miller. Moskva, 1996.

17 Paliiv. "Tuha za Evropeis'koiu Ukrainoiu”.

18 Iurii Andrukhovych. Dezoriientatsiia na mistsevosti. Sproby. Ivano-Frankivs'k: Lileia-NV, 1999, 29.

19 Andrukhovych. Dezoriientatsiia na mistsevosti. Sproby, 50.

20 Ibid. 60.

21 Ibid. 59-60.

22 Ibid. 6.

23 Iurii Andrukhovych. “Tsentral'no-skhidna reviziia," Suchasnist'.3 (200o). 5-32.

24. Andrukhovych. "Tsentral'no-skhidna reviziia"5.

25 Ibid. 16.

26 Ibid. 22.

27 Serhii Hrabovs'kyi. “Esse Andrukhovych." Krytyka IV. 7-8 (33-34) (lypen'-serpen' 200o).

28 Andrukhovych. "Tsentral'no-skhidna reviziia." 31. 